\title{
Assessment of Climate Change Impacts on Water Resources of Al-Adhaim, Iraq Using SWAT Model
}

\author{
Nahlah Abbasa1, Saleh A. Wasimia ${ }^{1}$, Nadhir Al-Ansari ${ }^{2}$ \\ ${ }^{1}$ School of Engineering \& Technology, Central Queensland University, Melbourne, Australia \\ ${ }^{2}$ Geotechnical Engineering, Lulea University of Technology, Lulea, Sweden \\ Email: n.abbas@cqu.edu.au, s.wasimi@cqu.edu.au,nadhir.alansari@ltu.se
}

How to cite this paper: Abbasa, N., Wasimia, S.A. and Al-Ansari, N. (2016) Assessment of Climate Change Impacts on Water Resources of Al-Adhaim, Iraq Using SWAT Model. Engineering, 8, 716-732. http://dx.doi.org/10.4236/eng.2016.810065

Received: September 30, 2016

Accepted: October 24, 2016

Published: October 27, 2016

Copyright $\odot 2016$ by authors and Scientific Research Publishing Inc. This work is licensed under the Creative Commons Attribution International License (CC BY 4.0).

http://creativecommons.org/licenses/by/4.0/ (c) (i) Open Access

\begin{abstract}
SWAT model (Sediment and Water Assessment Tool) was used to evaluate the impacts of climate change on water resources in Al-Adhaim Basin which is located in north east of Iraq. Al-Adhaim River is the main source of fresh water to Kirkuk City, one of the largest cities of Iraq. Recent studies have shown that blue and green waters of the basin have been manifesting increasing variability contributing to more severe droughts and floods apparently due to climate change. In order to gain greater appreciation of the impacts of climate change on water resources in the study area in near and distant future, SWAT (Soil and Water Assessment Tool) has been used. The model is first tested for its suitability in capturing the basin characteristics, and then, forecasts from six GCMs with about half-a-century lead time to 2046-2064 and one-century lead time to 2080-2100 are incorporated to evaluate the impacts of climate change on water resources under three emission scenarios: A2, A1B and B1. The results showed worsening water resources regime into the future.
\end{abstract}

\section{Keywords}

Al-Adhaim, SWAT, Sensitivity, Blue Water, Green Water, Iraq

\section{Introduction}

The water resources of any basin are influenced by several variables including precipitation, soil, land use and natural calamities such as cyclones, and induced catastrophes such as bushfires. Climate change has significant effects on the supply and demand balance of water resources universally [1] and regionally [2]. Where the water resources are constrained, the water balance is often fragile and the situation can be easily exacerbated by climate change [3] which can be unprecedented because the water system is vulnerable to climate change outside the range of historical events [4]. Climate 
change can have a considerable impact on the hydrological cycles mainly through the alteration of evapotranspiration and precipitation [5] [6]. The effects can strikingly manifest as severe droughts or intense floods. This in turn can have a significant impact on the water balance of a basin [7].

Iraq is classified as arid or semi-arid with less than $150 \mathrm{~mm}$ of annual rain and high evaporation rate. Its water balance is relatively delicate threatened by water scarcity that can significantly aggravate due to climate change [8]. Arguably, climate change is one of the major challenges confronting Iraq; its adverse effects on water resources can impact the environment and the economy, particularly the agricultural sector. There is a strong demand from decision makers for predictions about the potential impacts of climate change on the interval and amount of precipitation, which have consequences on sustaining and managing water resources appropriately and diminish water scarcity problem that has become noticeable [9].

In Northern Iraq, Al-Adhaim River is one of the fife tributaries of Tigris River. Al-Adhaim is the source of surface water for Kirkuk city. This basin has been suffering from water scarcity and pollution due to its extreme dry weather [9]. Up to date, water issues related to climate change in the Al-Adhaim catchment have not been well addressed within climate change analyses and climate policy construction [10]. Therefore, the main objective of this study has been to assess the potential future climatic changes on the water sources of Al-Adhaim, specifically blue and green waters. The computer-based hydrological model Soil and Water Assessment Tool (SWAT) has been used to explore the effects of climatic change on streamflow of the study area. The model was set at monthly scale using available spatial and temporal data and calibrated against measured streamflow. Climate change scenarios were obtained from general circulation models.

\section{Materials and Methods}

\subsection{Al-Adhaim}

Al-Adhaim or Nahr Al Uzaym (Figure 1) is located in northeast Iraq, rises from hilly and mountainous areas in Iraq. It drains about $13,000 \mathrm{~km}^{2}$ lies totally in Iraq in which no snowfall and rainfall is limited [11]. It is fed by rainfall only therefore, the occurrence of effective flow is during the wet season [12]. Al-Adhaim generates about 0.79 cubic billion meters annually at its convergence with the Tigris [13]. It links Tigris River approximately $13 \mathrm{~km}$ downstream of Balad city [14]. Its length is $230 \mathrm{~km}$ (from the source to the junction with the Tigris. The annual precipitation for the Al-Adhaim basin ranges from 80 to $330 \mathrm{~mm}$, and temperatures vary between $2^{\circ} \mathrm{C}$ and $48^{\circ} \mathrm{C}$. Al-Adhaim flow system is classified as an irregular flow system that depends intensely on precipitation [11]. This river runs dry in summer from May to October and high flow occurs during November to May. Accordingly, Al-Adhaim can be classified as an arid basin. Approximately $71 \%$ of the basin is covered by forest, and $29 \%$ by Agricultural Land-Row.

\subsection{Description of SWAT Model}

The Soil and Water Assessment Tool (SWAT) model [15] is a river watershed scale, 


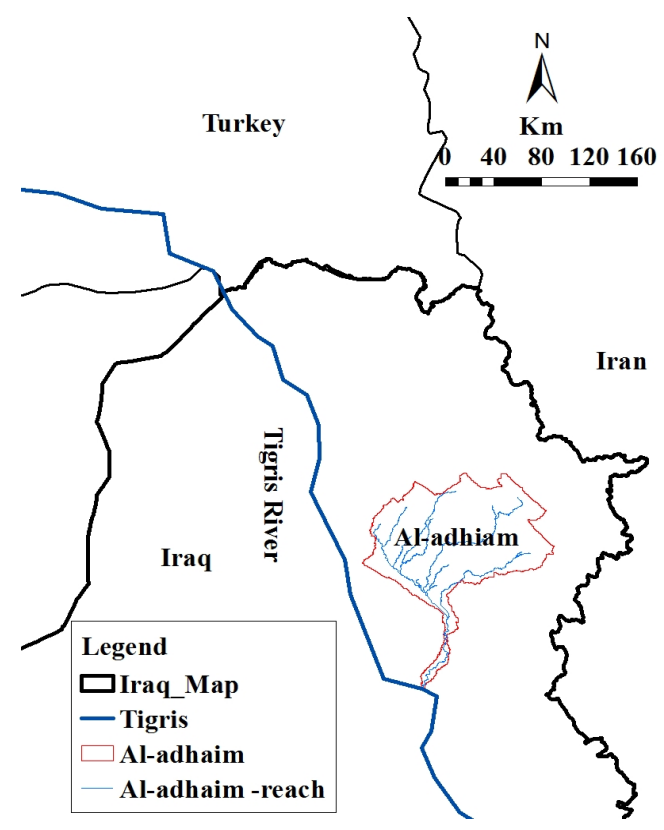

Figure 1. Location of Al-Adhaim basin.

semi-distributed and physically based continuous time (daily computational time step) model for analyzing hydrology and water quality at various watershed scales with varying soils, land use and management conditions on a long-term basis. Details of the model are well described by [16].

Land and routing phases are the two models used in this model. The land phase predicts the hydrological components (surface runoff, evapotranspiration, groundwater, lateral flow, ponds, tributary channels and return flow) while the routing phase is the movement of water, sediments, nutrients and organic chemicals via the channel network of the basin to the outlet. The estimation of surface runoff is done through two methods. The first is the SCS curve number method which is an empirical method to estimate the surface runoff based on studies of different rainfall-runoff relationships for small rural watersheds, then developed for different types of soils and land use [15] and the Green and Ampt infiltration method [16]. More details are given by [16].

\section{Model input}

A great amount of input data is essential for SWAT model to accomplish the tasks envisaged in this research. They are: digital elevation model (DEM), land use map, soil map, weather data and discharge data. These data were compiled from different sources. DEM data was obtained from Queensland Department of Natural Resources and Mines (https://data.qld.gov.au/), and land cover map from Queensland Government Data (https://www.dnrm.qld.gov.au/) and the soil map from the global soil map of the Food and Agriculture Organization of the United Nations [17]. Finally, weather and daily stream flow and water quality data were obtained from the Australian government's Bureau of Meteorology (http://www.bom.gov.au/climate/data/) and Queensland Department of Natural Resources and Mines/ Water Monitoring Portal (https://www.dnrm.qld.gov.au/water/water-monitoring-and-data/portal) respectively. 


\section{Model setup, calibration and evaluation}

The watershed is divided into sub-basins based on the elevation model (DEM). Thereafter, sub-basins are further delineated by Hydrologic Response Units (HRUs) which are defined as packages of land that have a unique slope, soil and land use area within the borders of the sub-basin. To calibrate the model, the sequential uncertainty fitting algorithm application (SUFI-2) embedded in the SWAT-CUP package [18] was used It calculates the Coefficient of Determination $\left(R^{2}\right)$ and the Nasch-Sutcliff efficiency (ENC) [19] to assess the goodness of fit between the measured and simulated data.

$$
R^{2}=\left[\frac{\sum_{i=1}^{n}\left(O_{i}-\bar{O}\right)\left(P_{i}-\bar{P}\right)}{\sum_{i=1}^{n}\left(O_{i}-\bar{O}\right)^{0.5}\left[\sum_{i=1}^{n}\left(P_{i}-\bar{P}\right)^{2}\right]^{0.5}}\right]^{2}
$$

where $O_{i}$ is the observed stream flow, $P_{i}$ is the simulated stream flow, $\bar{O}$ is the mean observed stream flow during the evaluation period and $\bar{P}$ is the mean simulated stream flow for the same period.

To find out how well the plot of the observed against the simulated values fits the 1:1 line $E N C$ value was used.

$$
E N C=1-\left[\frac{\sum_{i=1}^{n}\left(O_{i}-P_{i}\right)^{2}}{\sum_{i=1}^{n}\left(O_{i}-\bar{O}\right)^{2}}\right]
$$

For sensitivity analysis, which is computed based on the Latin Hypercube and multiple regression analysis. The multiple regression equation is defined as below.

$$
g=a+\sum_{i=1}^{m} \beta_{i}^{*} b_{i}
$$

where $g$ is the value of evaluation index for the model simulations, $\alpha$ is a constant in multiple linear regression equation, $\beta$ is a coefficient of the regression equation, $b$ is a parameter generated by the Latin hypercube method and $\mathrm{m}$ is the number of parameters.

For more details see [18] [19] [20].

\section{General Circulation Model (GCM) inputs}

For climate change prediction, six GCMs (CGCM3.1/T47, CNRM-CM3, GFDLCM2.1, IPSLCM4, MIROC3.2 (medres) and MRI CGCM2.3.2) were used under a very high emission scenario (A2), a medium emission scenario (A1B) and a low emission scenario (B1) for two future periods (2046-2064) and (2080-2100). The projected temperatures and precipitation were then input to the SWAT model to compare water resources in the basin with the baseline period (1980-2010) (Figure 2). BCSD method was used to downscale the GCM results [21].

\section{Sensitivity analysis}

Sensitivity analysis has been carried out for 25 parameters related to stream flow (Table 1), from which 12 most sensitive parameters have been considered, as is the usual practice, for implementing model calibration for the AlAdhaim basin.

$\mathrm{CN} 2$ was the dominant SWAT calibration parameter for the Al-Adhaim. In most 
SWAT applications in different watersheds, CN2 was found to be the most sensitive parameter [22]. CN2 has major impact on the amount of runoff generated from HRU, thus a relatively higher sensitivity index can be predicted for most of the basins [23]. SWAT is highly sensitive to ESCO for Al-Adhaim River mainly due to the higher mean air temperature and solar radiation which result in higher evapotranspiration losses in Al-Adhaim watershed (Table 2). Accordingly stream flow is highly sensitive to ESCO

Table 1. Description of input parameters of streamflow selected for model calibration.

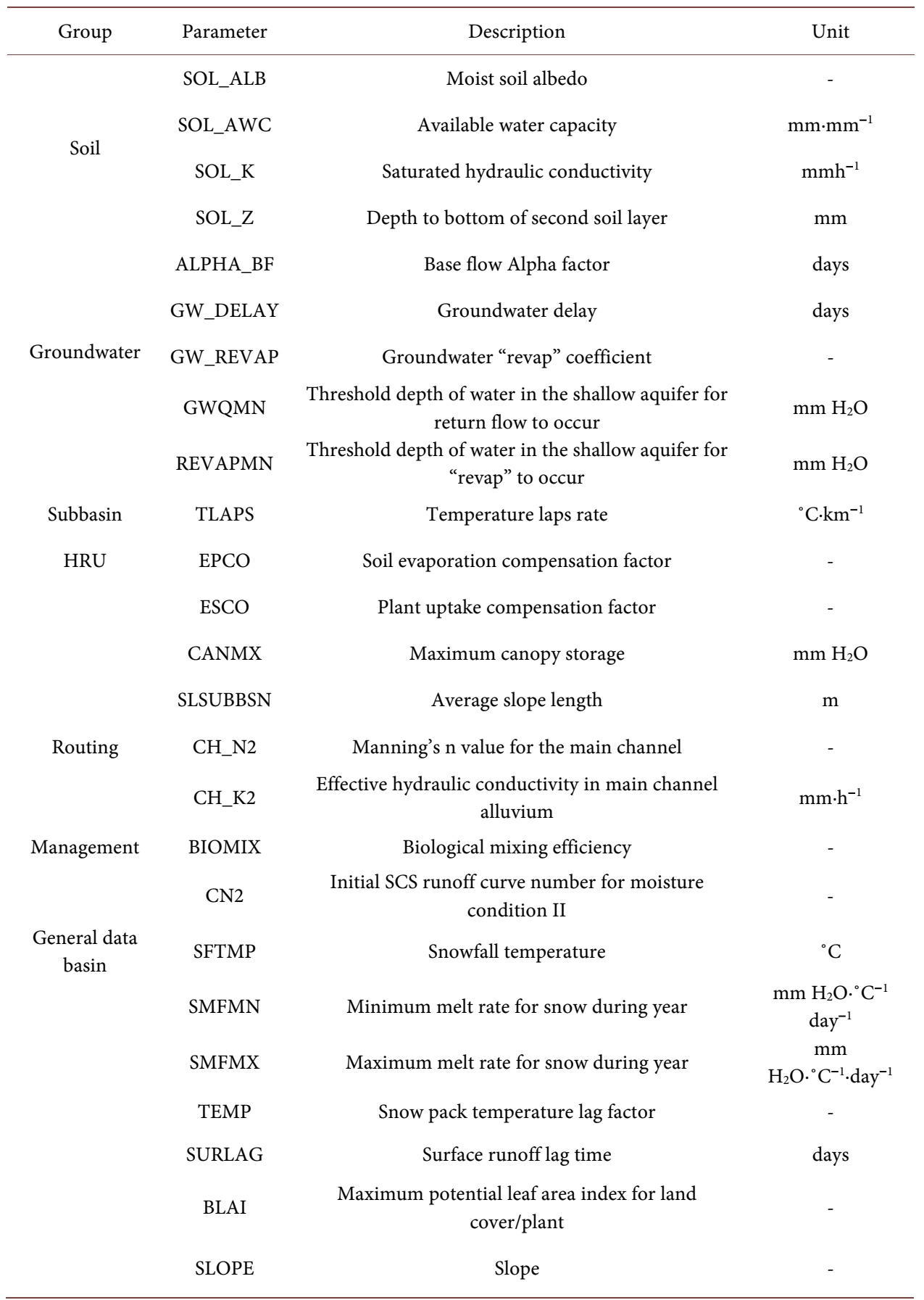


Table 2. Ranking of 12 highest sensitive parameters related to stream flow in the Al-Adhaim basin.

\begin{tabular}{cccc}
\hline Parameter & Al-Adhaim & Initial values & Fitted values \\
\hline CN2 & 1 & $-0.2-0.2$ & -0.10 \\
ESCO.hru & 2 & $0-0.2$ & 0.89 \\
SOL_AWC & 3 & $-0.2-0.4$ & 0.305 \\
ALPHA_BF & 4 & $0-1$ & 0.37 \\
SURLAG & 5 & $0.05-24$ & 14.4 \\
GW_DELAY & 6 & $50-450$ & 75.5 \\
HRU_SLP & 7 & $0-0.2$ & 0.017 \\
SFTMP & 8 & $-5-5$ & -3.1 \\
GWQMN & 9 & $0-2$ & 0.07 \\
SLSUBBSN & 10 & $0-0.2$ & 0.005 \\
CH_K2 & 11 & $5-130$ & 53.87 \\
GW_REVAP & 12 & $0-0.2$ & 0.17 \\
\hline
\end{tabular}

which directly affects the evapotranspiration losses from the watershed (Table 2). SOL_AWC came the third for the Al-Adhaim (Table 2). It can be seen clearly that SWAT was most sensitive to CN2, ESCO and SOL_AWC in arid Al-Adhaim Basin (Table 2). Similarly, [23] was found that SWAT model is highly sensitive to surface runoff parameters (CN2, ESCO, SOL_AWC) when the watershed is categorized as arid basin. Among the groundwater parameters, ALPHA-BE was observed to be the most sensitive parameter for all watersheds (Table 2). ALPHA-BE was ranked fourth for Al-Adhaim watershed, respectively. This result is consistent with the finding of [24], who found that ALPHA is highly sensitive groundwater parameter to SWAT calibration.

\section{Calibration and validation}

SWAT was calibrated and validated for AlAdhaim at the solo discharge station in the basin, Injanasation, on a monthly scale. The model was calibrated for thirteen years (1979-1991) and validated for six years (1992-1997) at the Injana discharge station. The first three years was set as a warm up.

The results of monthly discharge calibration and validation for the station showed good agreement with observed data as shown in Figure 2, Figure 3. $\mathrm{R}^{2}$ was 0.69 and ENC was 0.667 during the calibration. $\mathrm{R}^{2}$ and ENC increased to 0.80 and 0.76 , respectively during the validation.

\section{Trends in Precipitation, Blue Water, Green Water, Storage and Water Flow in the Past}

Using the calibrated model, annual precipitation, blue water (summation of water yield and deep aquifer recharge) and green water storage (soil water content) were estimated during the last three decades to identify the impacts of climate change on the water 


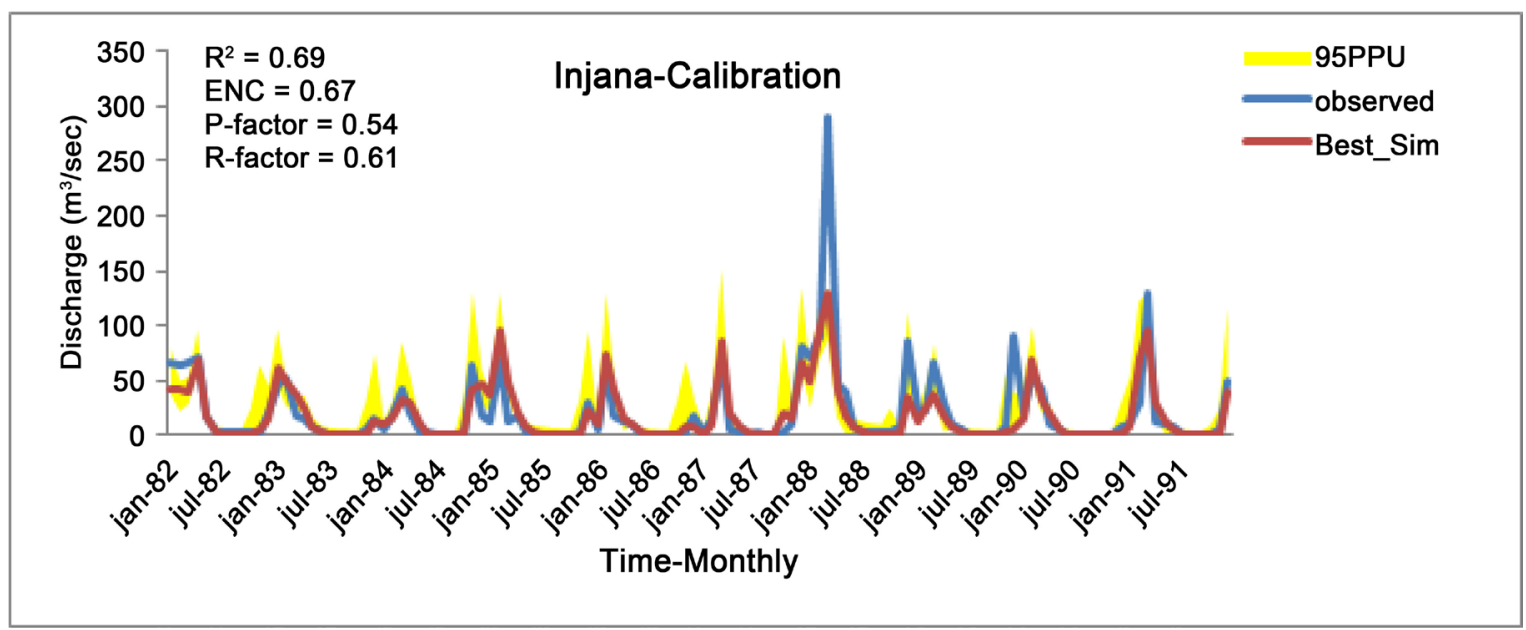

Figure 2. Calibration of the SWAT model at monthly scale at Injana station within Al-Adhaim.

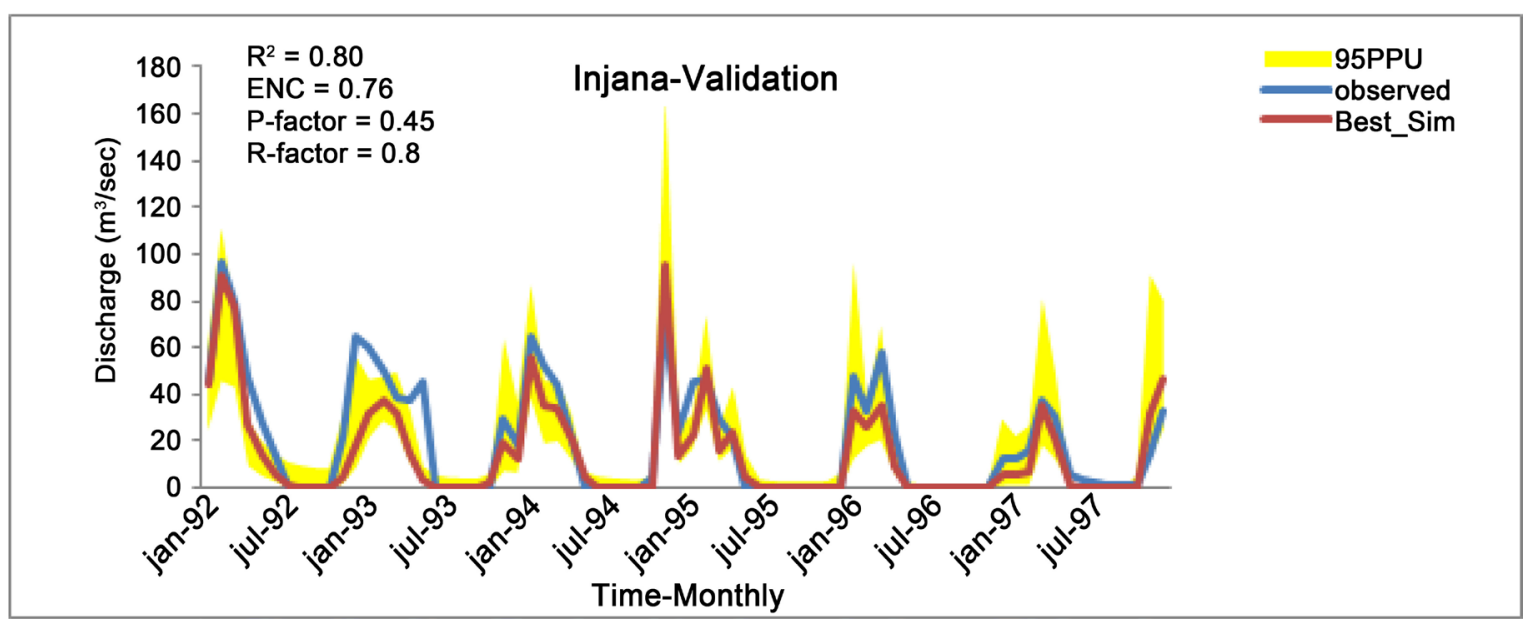

Figure 3. Validation of the SWAT model at monthly scale at Injana station within Al-Adhaim.

cycle components. Blue water is the freshwater humans can access for instream use or withdrawal. Green water storage does not provide direct access to humans but sustains natural flora and rain-fed agriculture. Green water flow is actual evapotranspiration. The model outputs matched observations.

Figure 4 captures the spatial distribution of precipitation in HRUs over three consecutive decades. Generally, precipitation decreased from the east to the west of the basin. Figure 4 showed a general declining trend in precipitation over time. The 1990s and 2000 s decades experienced decreases by about $24 \%$ and $43 \%$ compared to 1980 s decade, respectively (Table 3 ).

Blue water and green water storage in the Al-Adhaim basin decreased from east to west (Figure 5 and Figure 6). Generally, green water tracks blue water. The spatial patterns of the blue and green water flows are largely influenced by the spatial patterns of precipitation. In addition, land cover contributes to the shaping of spatial patterns. The average annual blue water and green water storage for the entire catchment significantly decreased from 1980 s to 2000 s. It is possible that the decreasing trends in the av- 
erage annual blue water and green water are attributed to climate change. Green water flow was relatively stable during the entire period (Table 3 ) due to the assumption that land cover/land use remained unchanged during the period of 1980 to 2010.

$(1980-1990)$

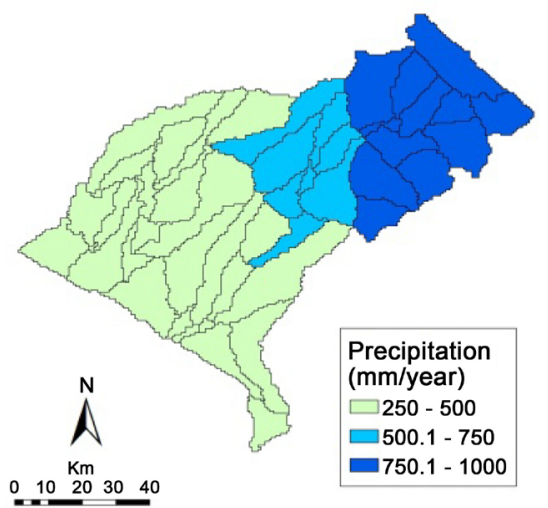

$(1990-2000)$

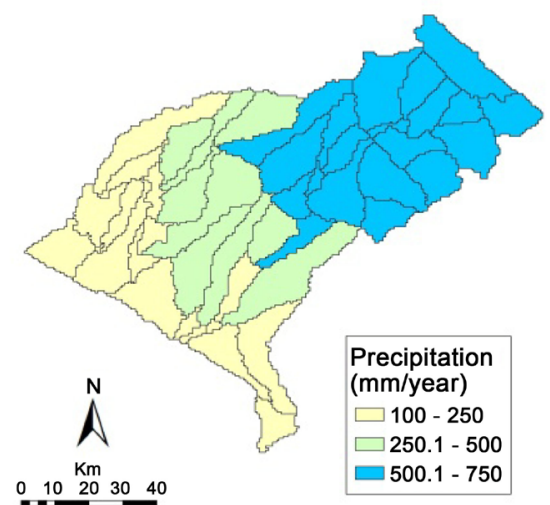

(2000-2010)

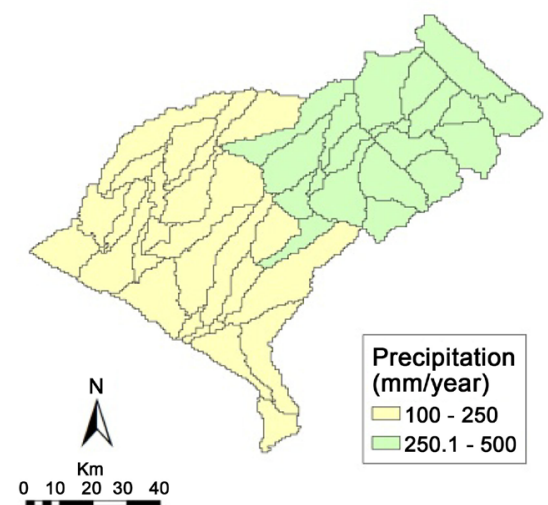

Figure 4. Spatial distribution of precipitation in the Al-Adhaim basin over three consecutive decades.

$(1980-1990)$

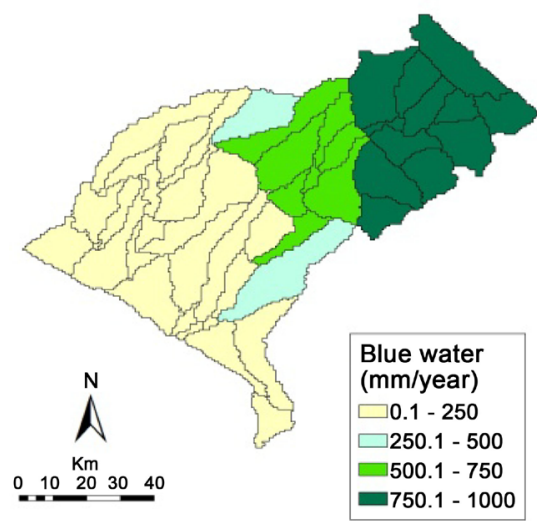

$(1990-2000)$

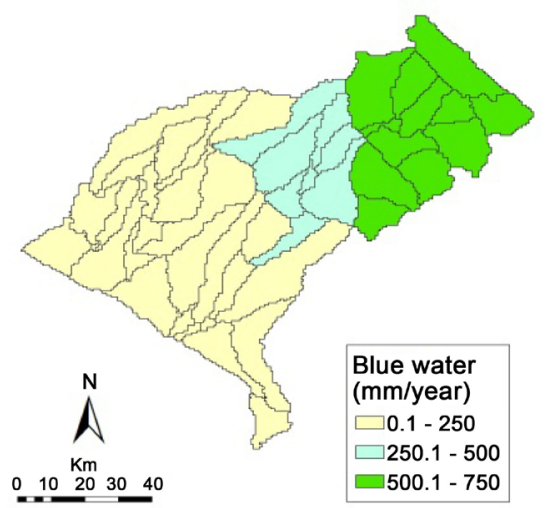

(2000-2010)

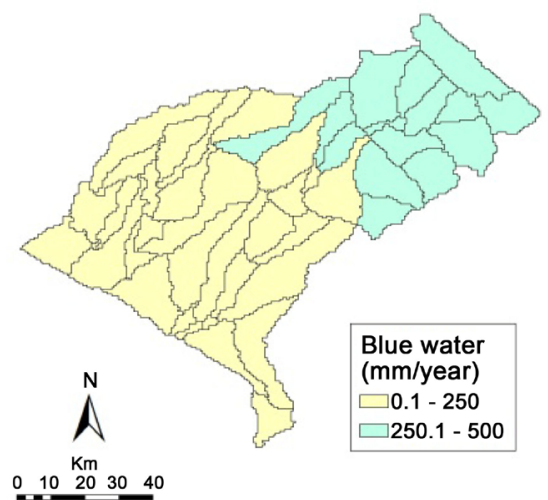

Figure 5. Spatial distribution of blue water in the Al-Adhaim basin over three consecutive decades.

(1980-1990)

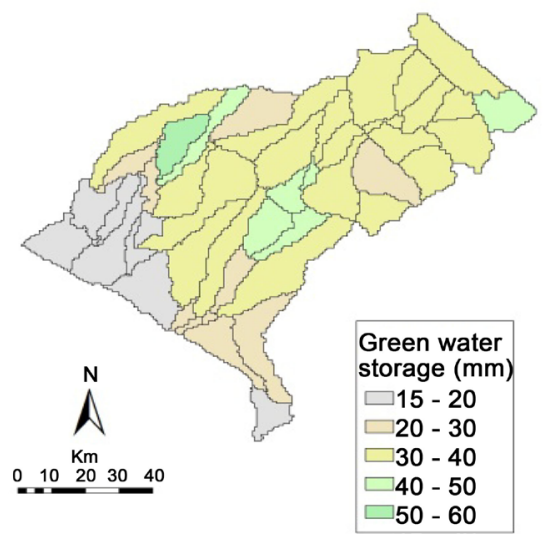

$(1990-2000)$

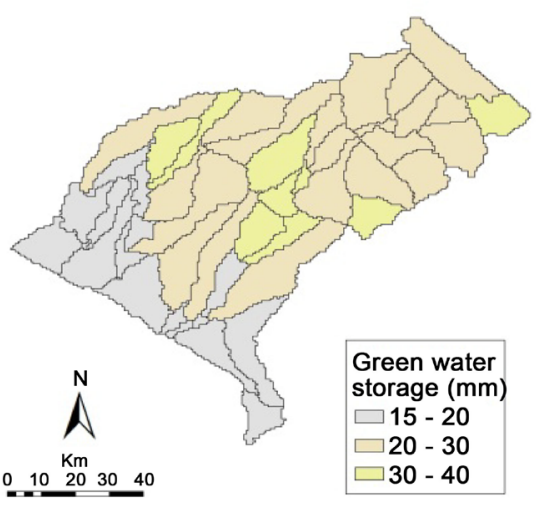

$(2000-2010)$

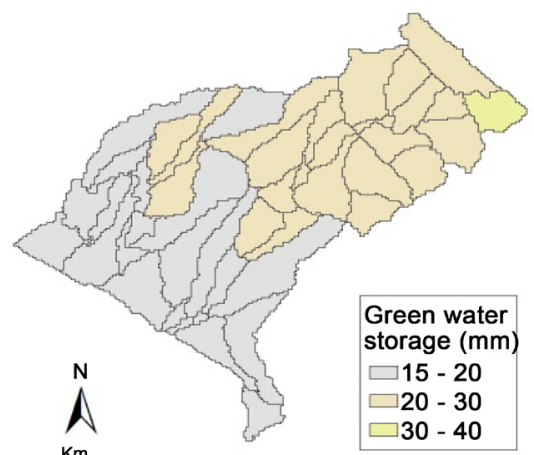

$.10 \quad 2030 \quad 40$

Figure 6. Spatial distribution of green water storage in the Al-Adhaim basin over three consecutive decades. 
Table 3. Relative changes in precipitation, blue water and green water in the Al-Adhaim basin over three decades.

\begin{tabular}{cccc}
\hline & \multicolumn{3}{c}{ Rate of relative change in the last three decades } \\
\hline Water component & 1990s vs 1980s & 2000s vs 1990s & 2000s vs 1980s \\
\hline Precipitation & -0.24 & -0.25 & -0.43 \\
Blue water & -0.40 & -0.52 & -0.70 \\
Green water storage & -0.17 & -0.17 & -0.31 \\
Green water flow & -0.12 & -0.13 & -0.11 \\
\hline
\end{tabular}

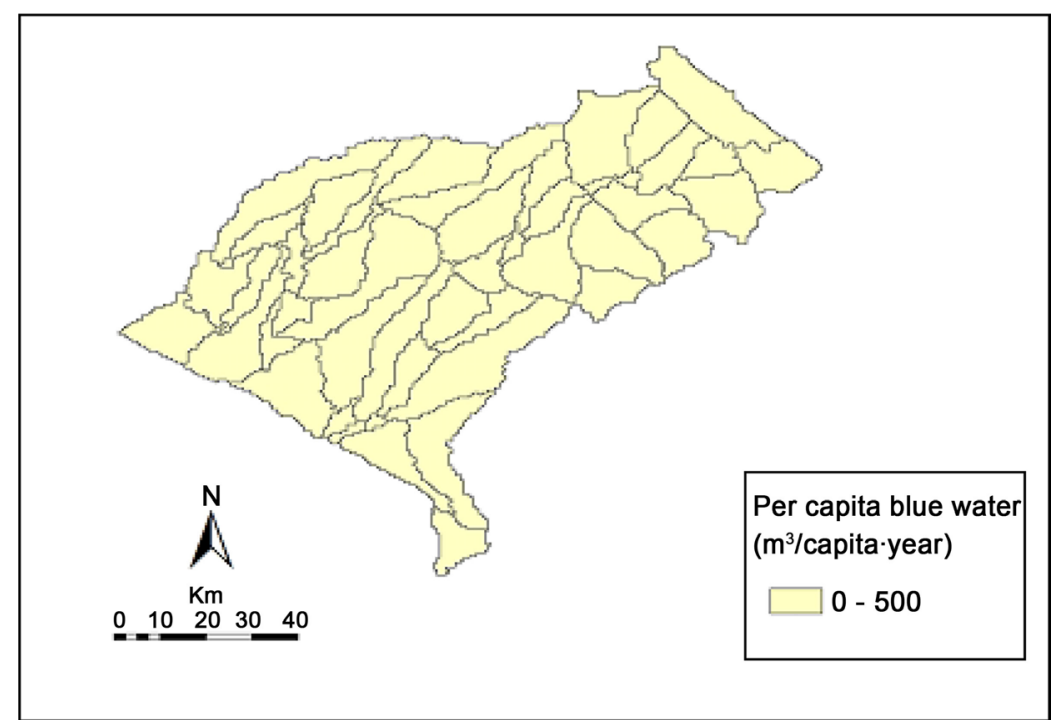

Figure 7. Water scarcity in each modeled Al-Adhaim subbasin represented by the modeled 1980 to 2010 annual average blue water flow availability per capita per year (using population of 2005) the average (Avg.) value of the 95PPU range.

\section{Blue Water Scarcity Indicators}

The calibrated model was used for water scarcity analysis. Among a large number of water scarcity indicators, the most widely applied and accepted is the water stress threshold [25], defined as $1700 \mathrm{~m}^{3} \cdot$ capita $^{-1} \cdot \mathrm{year}^{-1}$ introduced by [26], which was used in this study. The $1700 \mathrm{~m}^{3} \cdot$ capita $^{-1} \cdot \mathrm{year}^{-1}$ is calculated based on estimations of water needs in the household, agriculture, industry and energy sectors, and the demand of the environment [25]. A value equal or greater than $1700 \mathrm{~m}^{3} \cdot \mathrm{capita}^{-1} \cdot \mathrm{year}^{-1}$ is considered as adequate to meet water demands. When water supply drops below $1000 \mathrm{~m}^{3} \cdot \mathrm{capita}^{-1} \cdot \mathrm{year}^{-1}$, it is referred to as water scarcity and below $500 \mathrm{~m}^{3} \cdot \mathrm{capita}^{-1} \cdot \mathrm{year}^{-1}$ is extreme scarcity. The water availability per capita and water stress indicators were estimated for each of the 42 sub-basins of the Al-Adhaim basin using the 2.5 arcmin population map available from the Center for International Earth Science (CIESIN) Gridded Population of the World (GPW, version 3, http://sedac.ciesin.columbia.edu/gpw) for 2005. Figure 7 demonstrates the spatial distribution of water resources per capita per year during the period of 1980-2010 based on the population estimates of the year of 2005. The total area of 
the basin experienced extreme water scarcity.

\section{The Impacts of Climate Change on Temperature and Precipitation under A2, A1B, B1 Emission Scenarios}

Mean annual temperature and precipitation outputs from the six GCMs identified earlier were processed for the Al-Adhaim basin under three scenarios (A2, A1B, B1). Table 4 captures the projected changes in mean annual temperature for two future periods (2046-2064) and (2080-2100) relative to base period (1980-2010). Changes in mean temperature tend to be more consistent than precipitation. All the models showed consistent increasing trends in temperature. GFDL-CM2.1 projected the highest changes in temperature and MRI CGCM2.3.2 projected the lowest changes in temperature. Mean annual temperature for six models indicated that mean temperature will increase by $2.3^{\circ} \mathrm{C}$ under A2 followed by $2^{\circ} \mathrm{C}$ under AIB and then $1.6^{\circ} \mathrm{C}$ for near future. For far future the mean temperature will increase by $4.9^{\circ} \mathrm{C}, 4^{\circ} \mathrm{C}$ and $3.25^{\circ} \mathrm{C}$ under $\mathrm{A} 2$, A1B and B1, respectively.

Figure 8 shows the anomaly maps of precipitation distribution (maps of percent deviation from historic data, 1980-2010) for A2, A1B and B1 scenarios for the periods 2046-2064 and 2080-2100 for the average change of multi-GCM ensemble. A2 emission scenario produced the highest decreases while B1 emission scenario gave the lowest reductions for both periods. Precipitation will decrease by $26 \%, 14 \%$ and $7 \%$ under A2, $\mathrm{A} 1 \mathrm{~B}$ and B1, respectively in near future (2046-2064). The reductions will increase to $37 \%, 25 \%$ and $16 \%$ under A2, A1B and B1 respectively in distant future (2080-2100).

\subsection{Impacts of Climate Change on Blue and Green Water Flows}

Figure 9 captures the anomaly maps of blue water distribution (maps of percent deviation from historic data, 1980-2010) for A2, A1B and B1 scenarios for the periods 2046-2064 and 2080-2100 for the average change of multi-GCM ensemble. The half-

Table 4. GCM predicted changes in the mean annual temperature of the future under A2, A1B and $\mathrm{B} 1$ scenarios.

\begin{tabular}{ccccccc}
\hline \multicolumn{5}{c}{ GCM names predicting changes in mean annual temperature $\left({ }^{\circ} \mathrm{C}\right)$} \\
\hline Period & CGCM3.1/T47 & CNRM-CM3 & GFDL-CM2.1 & PSLCM4 & MIROC3.2 & MRI CGCM2.3.2 \\
\hline A2 & & & & & & \\
$2046-2064$ & 1.9 & 3.4 & 3.65 & 2.45 & 1.65 & 1.15 \\
$2080-2100$ & 5.2 & 5.5 & 5,4 & 5.2 & 4.3 & 3.8 \\
A1B & & & & & \\
$2046-2064$ & 1.5 & 2.5 & 2.9 & 2.7 & 1.3 & 1.1 \\
$2080-2100$ & 4.2 & 5 & 4.8 & 4.2 & 3.3 & 2.78 \\
B1 & & & & & & 1 \\
$2046-2064$ & 1.5 & 2.7 & 2.9 & 0.9 & 1.1 & 2.3 \\
$2080-2100$ & 3.8 & 3.2 & 4 & 3.2 & 3 & \\
\hline
\end{tabular}


(a)

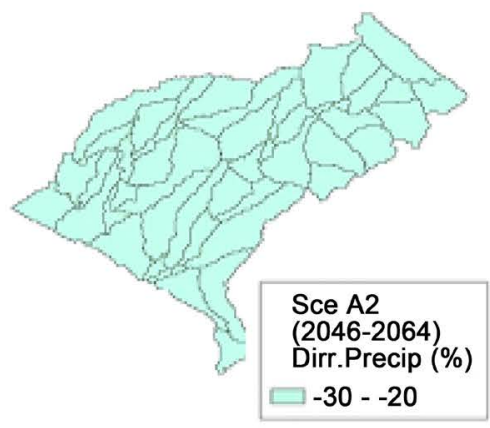

(c)

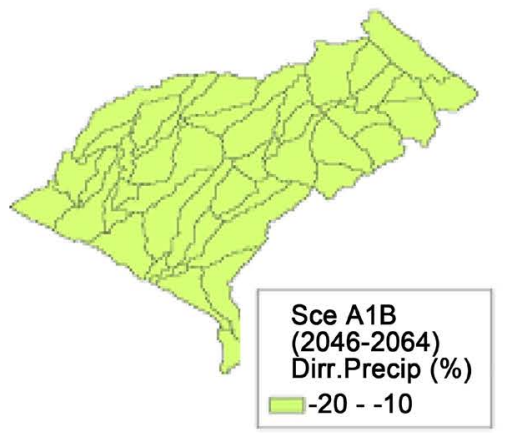

(e)

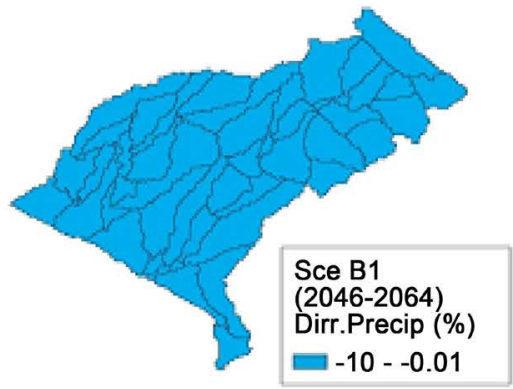

0

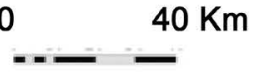

(b)

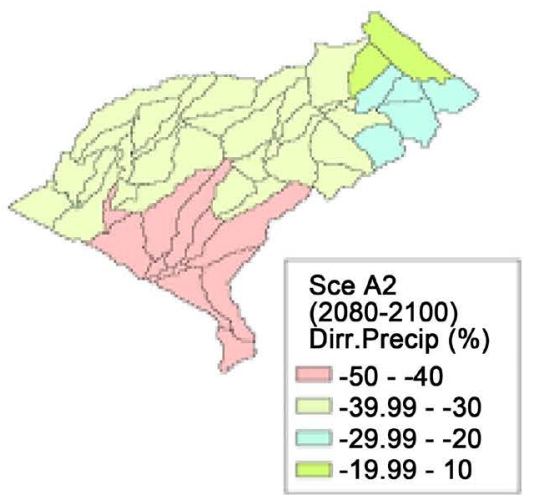

(d)

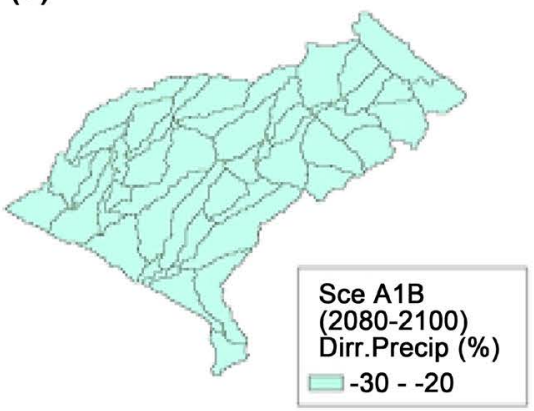

(f)

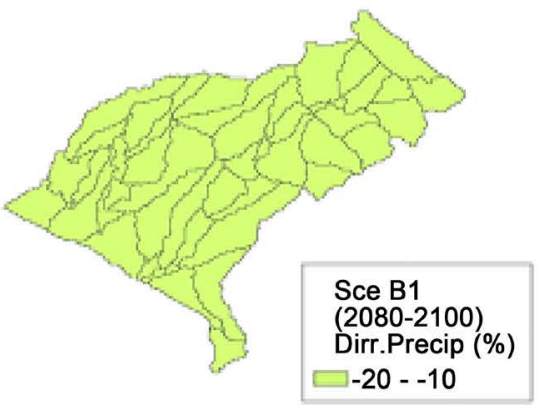

N

A

Figure 8. The impacts of climate change on the precipitation of the basin (a) Anomaly based on scenario A2 for the period of 2046-2064; (b) Anomaly for A2 to 2080-2100; (c) Anomaly for A1B to 2046-2064; (d) Anomaly for A1B to 2080-2100; (e) Anomaly for B1 to 2046-2064; and (f) Anomaly for B1 to 2080-2100. 


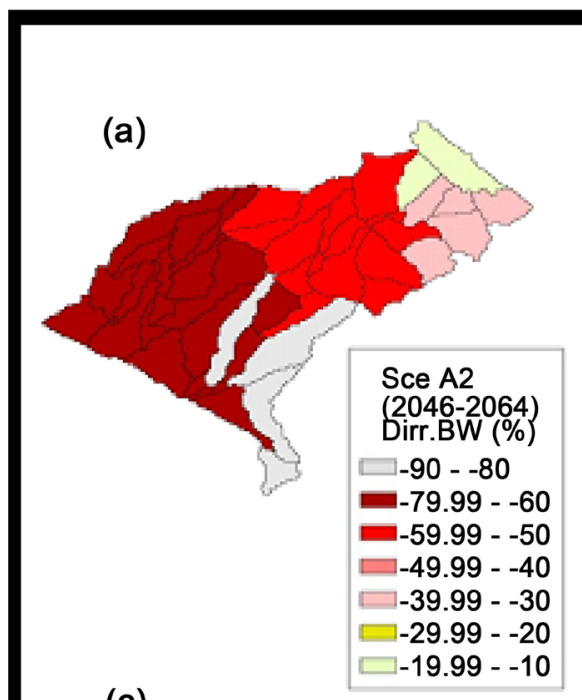

(c)
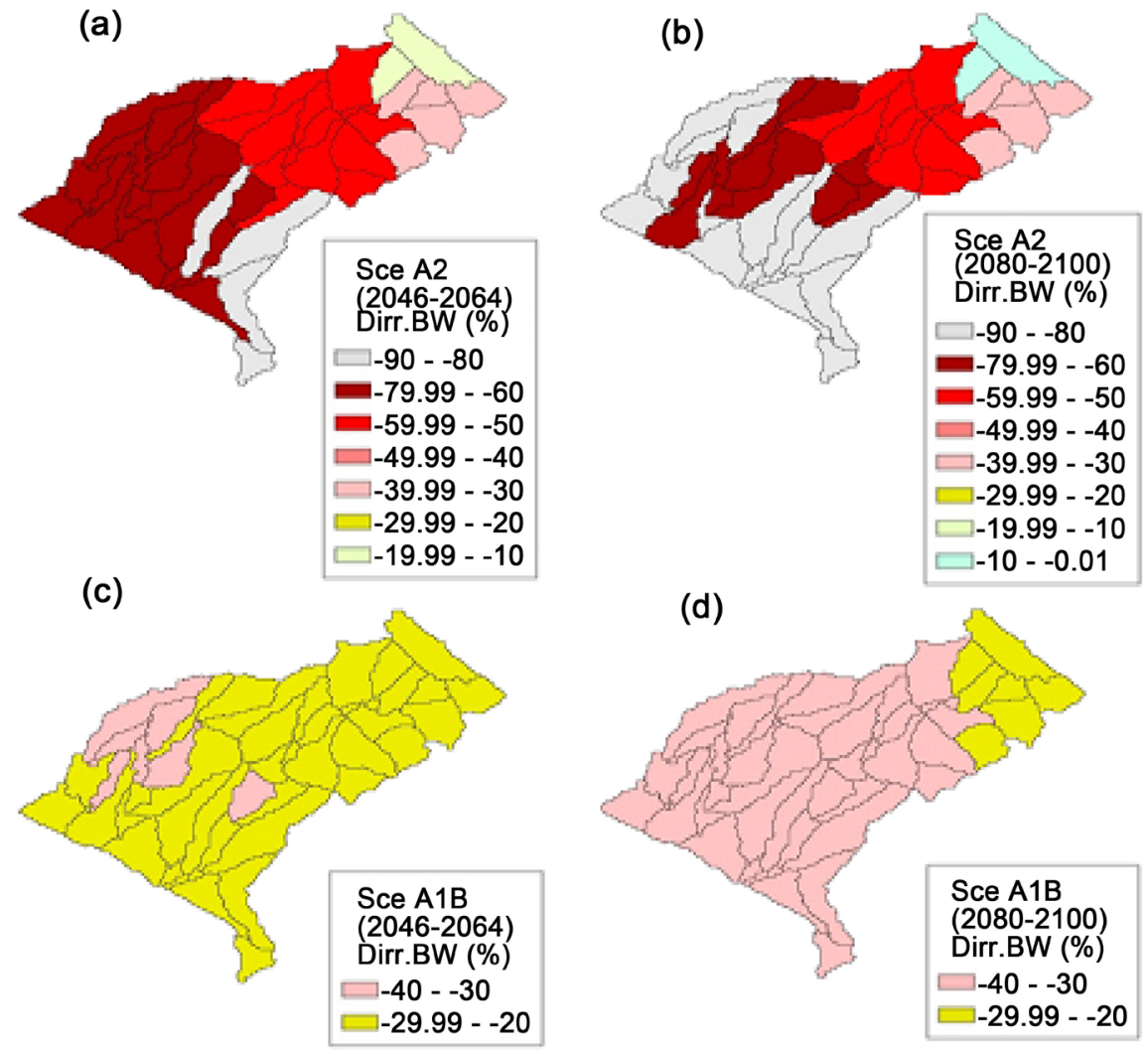

(e)

(f)
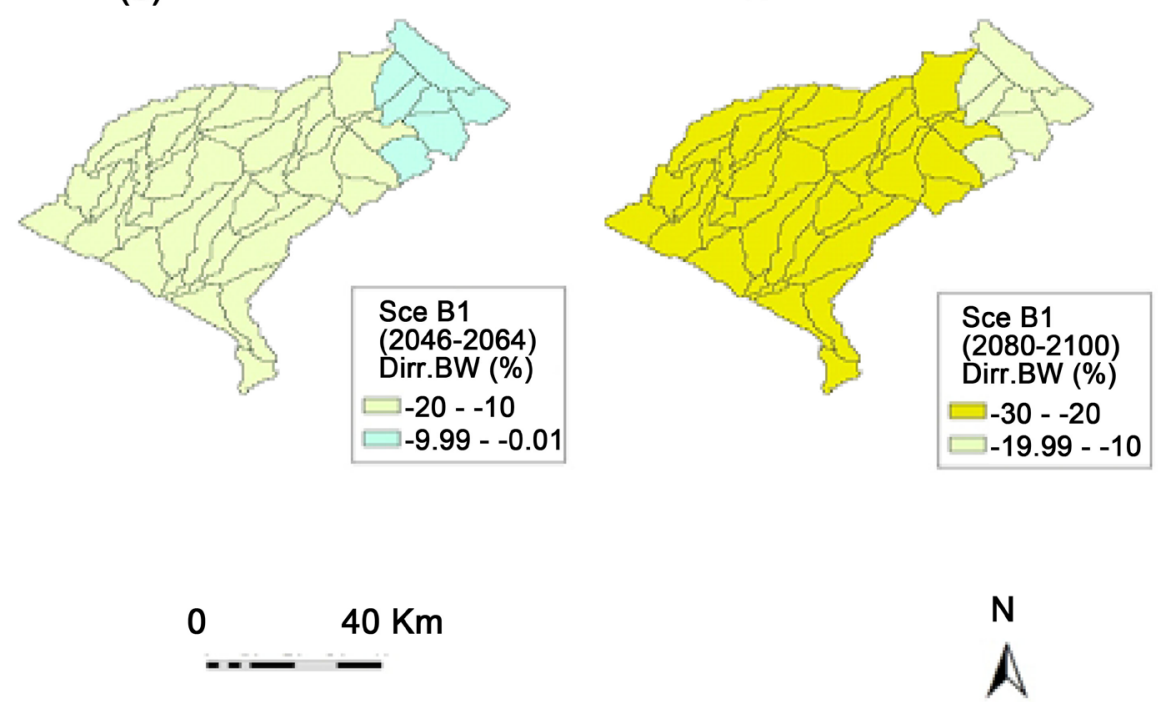

Figure 9. The impacts of climate change on the green water storage of the basin. (a) Anomaly based on scenario A2 for the period of 2046-2064; (b) Anomaly for A2 to 2080-2100; (c) Anomaly for A1B to 2046-2064; (d) Anomaly for A1B to 2080-2100; (e) Anomaly for B1 to 2046-2064, and (f) Anomaly for B1 to 2080-2100. 
(a)

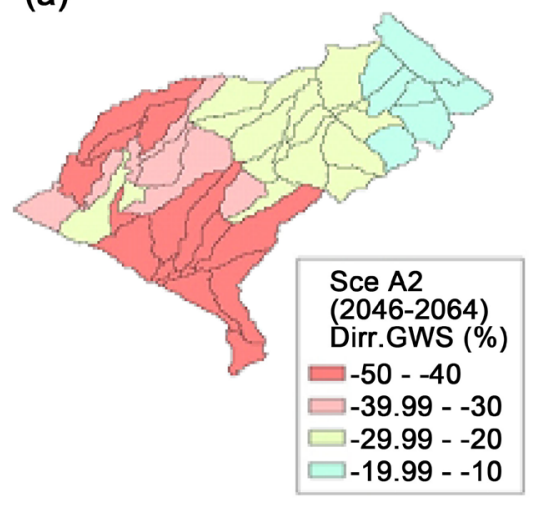

(c)

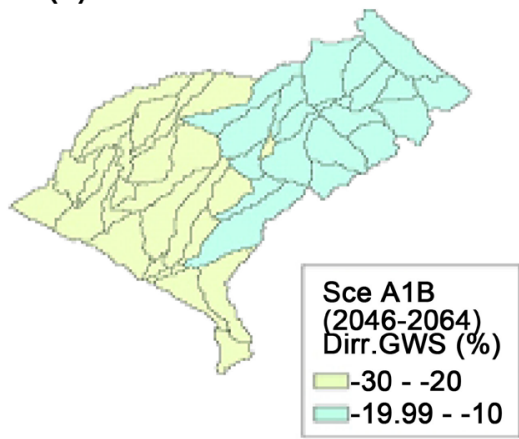

(e)

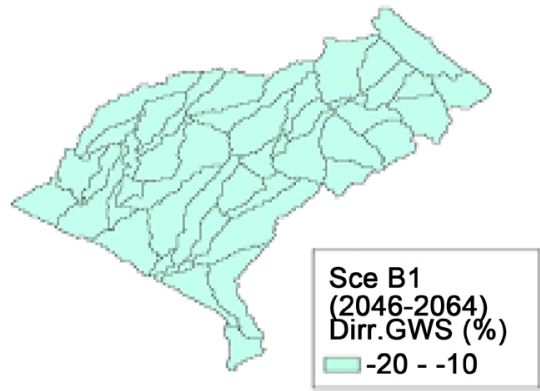

(b)

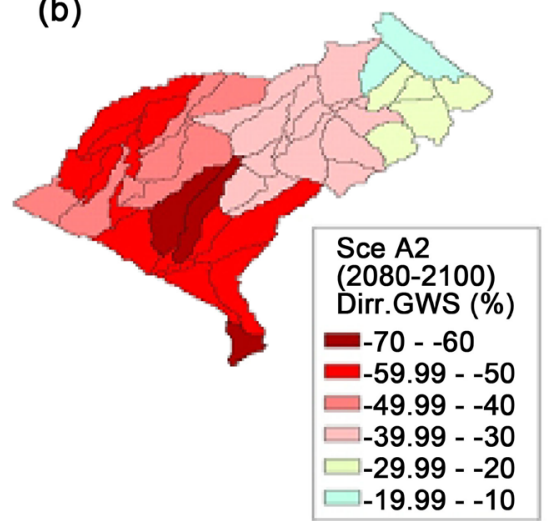

(d)

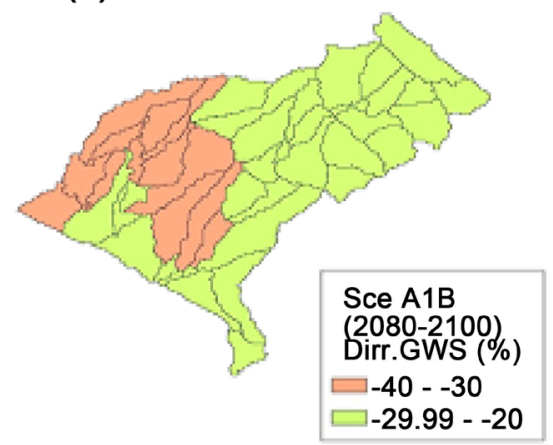

(f)

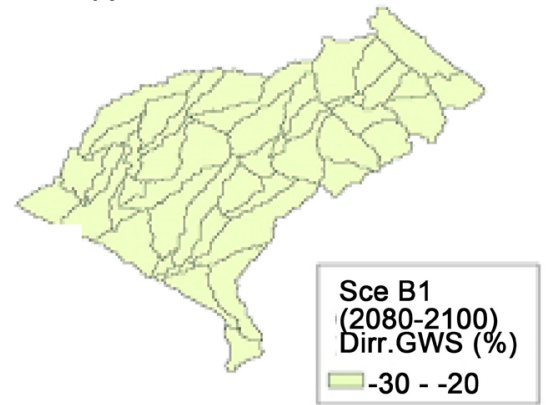

Figure 10. The impacts of climate change on the green water storage of the basin. (a) Anomaly based on scenario A2 for the period of 2046-2064; (b) Anomaly for A2 to 2080-2100; (c) Anomaly for A1B to 2046-2064; (d) Anomaly for A1B to 2080-2100; (e) Anomaly for B1 to 2046-2064, and (f) Anomaly for B1 to 2080-2100. 
(a)

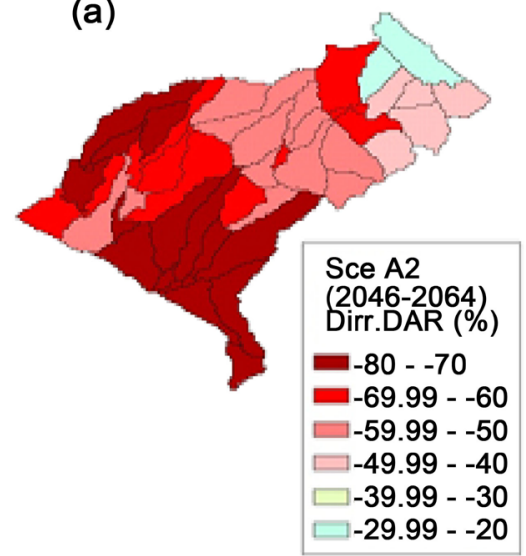

(c)

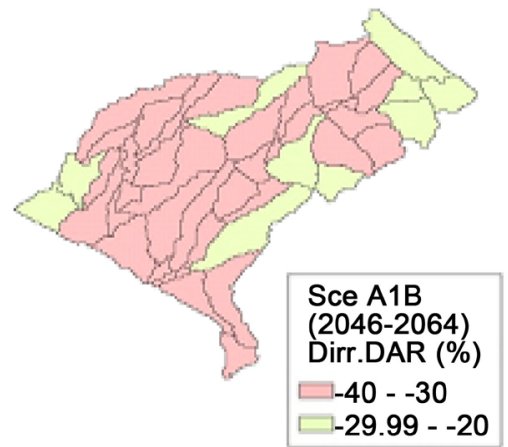

(e)

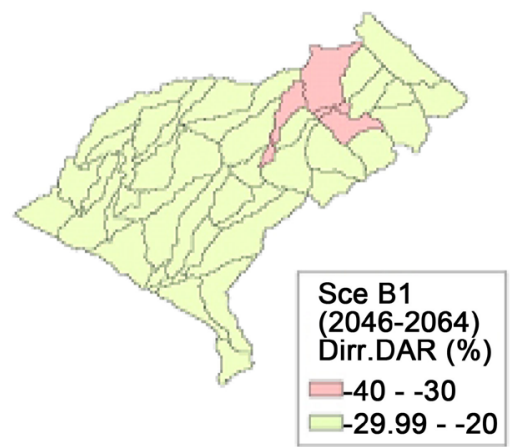

(b)

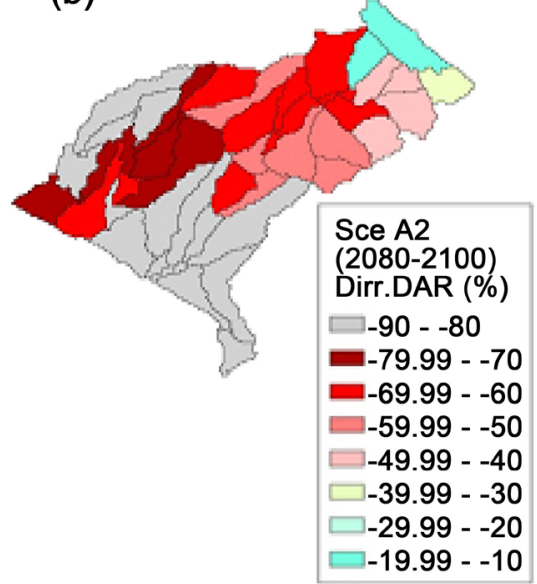

(d)

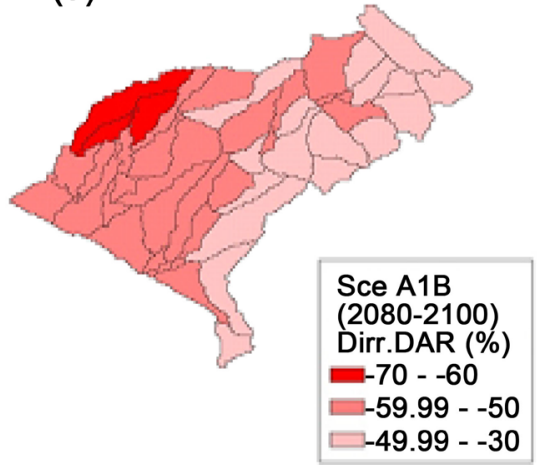

(f)

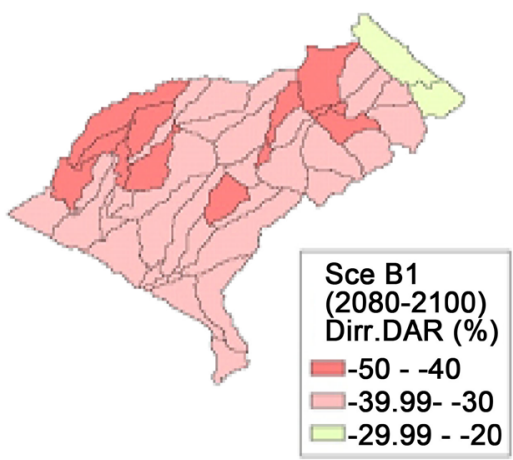

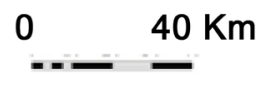

$\mathbf{N}$

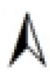

Figure 11. The impacts of climate change on the blue water of the basin. (a) Anomaly based on scenario A2 for the period of 2046-2064; (b) Anomaly for A2 to 2080-2100; (c) Anomaly for A1B to 2046-2064; (d) Anomaly for A1B to 2080-2100; (e) Anomaly for B1 to 2046-264; and (f) Anomaly for B1 to 2080-2100. 
century projection (2046-2064) showed a decrease in blue water under all emission scenarios for the whole basin. A2 scenario projected the highest reduction (62\%) followed by A1B (34\%) and then B1 (23\%). In the one-century future, the reduction will increase to $66 \%, 37 \%$ and $27 \%$ under A2, A1B and B1 emission scenarios, respectively. Similarly, green water storage will decrease under the three emission scenarios for the two future periods, which is captured in Figure 10. Green water flow calculations (maps not shown) indicated a slight decrease in evapotranspiration due to assumption that land cover would not significantly change from the period of 1980 to 2010 in the future.

\subsection{Impacts of Climate Change on Deep Aquifer Recharge}

Figure 11 captures the anomaly maps of blue water distribution (maps of percent deviation from historic data, 1980-2010) for A2, A1B and B1 scenarios for the periods 2046-2064 and 2080-2100 for the average change of multi-GCM ensemble All scenarios in the near and far future indicated that the basin will experience decreases in ground water recharge.

\section{Conclusion}

SWAT model was successfully applied for the Al-Adhaim basin at monthly time steps. The model was calibrated and validated at Injana hydrological station. The calibration and validation results showed good performance of the model in simulating hydrological processes. The calibrated model was used to identify the impacts of climate change on blue and green water over last three decades. It was also used to project blue and green water and deep aquifer recharge for near future (2046-2064) and far future (2080-2100) under three emission scenarios (A2, A1B, B1) using six GCMs. All models under three emission scenarios predicted that whole basin will be extremely dry in near and far future. The results of this study may enable decision makers to find a suitable water resources management and crop production for future.

\section{References}

[1] Arnell, N.W., Vuuren, D.P. and Isaac, M. (2011) The Implications of Climate Policy for the Impacts of Climate Change on Global Water Resources. Global Environmental Change, 21, 592-603. http://dx.doi.org/10.1016/j.gloenvcha.2011.01.015

[2] Tong, S.T.Y., Sun, Y., Ranatunga, T., He, J. and Yang, Y.J. (2012) Predicting Plausible Impacts of Sets of Climate and Land Use Change Scenarios on Water Resources. Applied Geography, 32, 477-489. http://dx.doi.org/10.1016/j.apgeog.2011.06.014

[3] Tabari, H. and Willems, P. (2016) Daily Precipitation Extremes in Iran: Decadal Anomalies and Possible Drivers. Journal of American Water Resources Association, 52, 541-599. http://dx.doi.org/10.1111/1752-1688.12403

[4] Borgomeo, E., Pflug, G., Hall, J.W. and Hochrainer-Stigler, S. (2015) Assessing Water Resource System Vulnerability to Unprecedented Hydrological Drought Using Copulas to Characterize Drought Duration and Deficit. Water Resources Research, 51, 8927-8948. http://dx.doi.org/10.1002/2015WR017324 
[5] Mimikou, M.A., Baltas, E., Varanou, E. and Pantazis, K. (2000) Regional Impacts of Climate Change on Water Resources Quantity and Quality Indicators. Journal of Hydrology, 234, 95-109. http://dx.doi.org/10.1016/S0022-1694(00)00244-4

[6] Xuan, Z. and Chang, N.B. (2014) Modeling the Climate-Induced Changes of Lake Ecosystem Structure under the Cascade Impacts of Hurricanes and Droughts. Ecological Modelling, 288, 79-93. http://dx.doi.org/10.1016/j.ecolmodel.2014.05.014

[7] Winter, J.M. and Eltahir, E.A.B. (2012) Modeling the Hydroclimatology of the Midwestern United States. Part 1: Current Climate. Climate Dynamics, 38, 573-593.

http://dx.doi.org/10.1007/s00382-011-1182-2

[8] IPCC (2007) Climate Change 2007: Impacts, Adaptation and Vulnerability: Contribution of Working Group II to the Fourth Assessment Report of the Intergovernmental Panel on Climate Change. Cambridge University Press, Cambridge.

[9] Al-Ansari, N., Ali, A.A. and Knutsson, S. (2014) Present Conditions and Future Challenges of Water Resources Problems in Iraq. Journal of Water Resource and Protection, 6, 10661098. http://dx.doi.org/10.4236/jwarp.2014.612102

[10] Issa, I.E., Al-Ansari, N., Sherwany, G. and Knutsson, S. (2014) Expected Future of Water Resources within Tigris-Euphrates Rivers Basin, Iraq. Journal of Water Resource and Protection, 6, 421-432. http://dx.doi.org/10.4236/jwarp.2014.65042

[11] Abdulla, F. and Al-Badranih, L. (2000) Application of a Rainfall-Runoff Model to Three Catchments in Iraq. Hydrological Sciences Journal, 45, 13-25.

http://dx.doi.org/10.1080/02626660009492303

[12] Al-Kadhimi, A.M., Ahmed, L.A. and Al-Mphergee, R.Y.A. (2011) Runoff Curves Development for Al-Adhaim Catchment Using Digital Simulation Models. Jordan Journal of Civil Engineering, 5, 229-244.

[13] Jaradat, A. (2003) Agriculture in Iraq: Resources, Potentials, Constraints, Research Needs and Priorities. Food, Agriculture and Environment, 1, 160-166.

[14] UN-ESCWA, BGR (2013) United Nations Economic and Social Commission for Western Asia; Bundesanstalt für Geowissenschaften und Rohstoffe. Inventory of Shared Water Resources in Western Asia, Beirut.

[15] Arnold, J.G., Srinivasan, R., Muttiah, R.S. and Williams, J.R. (1998) Large Area Hydrologic Modeling and Assessment Part I: Model Development1. Wiley Online Library.

[16] Green, W.H. and Ampt, G. (1911) Studies on Soil Physics, 1. The Flow of Air and Water through Soils. Journal of Agriculture Science, 4, 1-24.

[17] FAO (1995) The Digital Soil Map of the World and Derived Soil Properties, Version 3.5. Food and Agriculture Organization of the United Nations, Rome.

[18] Abbaspour, K.C., Yang, J., Maximov, I., Siber, R., Bogner, K., Mieleitner, J., Zobrist, J. and Srinivasan, R. (2007) Modelling Hydrology and Water Quality in the Pre-Alpine/Alpine Thur Watershed Using SWAT. Journal of Hydrology, 333, 413-430. http://dx.doi.org/10.1016/j.jhydrol.2006.09.014

[19] Nash, J. and Sutcliffe, J.V. (1970) River flow Forecasting through Conceptual Models Part I-A Discussion of Principles. Journal of hydrology, 10, 282-290. http://dx.doi.org/10.1016/0022-1694(70)90255-6

[20] Moriasi, D., Arnold, J., Van Liew, M., Bingner, R., Harmel, R. and Veith, T. (2007) Model Evaluation Guidelines for Systematic Quantification of Accuracy in Watershed Simulations. Soil \& Water Division of American Society of Agricultural and Biological Engineers, 50, 885-900.

[21] Maurer, E., Brekke, L., Pruitt, T., Thrasher, B., Long, J., Duffy, P., Dettinger, M., Cayan, D. 
and Arnold, J. (2014) An Enhanced Archive Facilitating Climate Impacts and Adaptation Analysis. Bulletin of the American Meteorological Society, 95, 1011-1019.

http://dx.doi.org/10.1175/BAMS-D-13-00126.1

[22] Cibin, R., Sudheer, K.P. and Chaubey, I. (2010) Sensitivity and Identifiability of Stream Flow Generation Parameters of the SWAT Model. Hydrological Processes, 24, 1133-1148. http://dx.doi.org/10.1002/hyp.7568

[23] Veith, T., Van Liew, M., Bosch, D. and Arnold, J. (2010) Parameter Sensitivity and Uncertainty in SWAT: A Comparison across five USDA-ARS Watersheds. Transactions of the ASABE, 53, 1477-1486. http://dx.doi.org/10.13031/2013.34906

[24] Li, Z., Xu, Z., Shao, Q. and Yang, J. (2009) Parameter Estimation and Uncertainty Analysis of SWAT Model in Upper Reaches of the Heihe River Basin. Hydrological Processes, 23, 2744-2753. http://dx.doi.org/10.1002/hyp.7371

[25] Rijsberman, F.R. (2006) Water Scarcity: Fact or Fiction? Journal of Agricultural Water Management, 80, 5-22. http://dx.doi.org/10.1016/j.agwat.2005.07.001

[26] Falkenmark, M. (1989) The Massive Water Scarcity Now Threatening Africa: Why Isn't It Being Addressed? Ambio, 18, 112-118.

Submit or recommend next manuscript to SCIRP and we will provide best service for you:

Accepting pre-submission inquiries through Email, Facebook, LinkedIn, Twitter, etc. A wide selection of journals (inclusive of 9 subjects, more than 200 journals)

Providing 24-hour high-quality service

User-friendly online submission system

Fair and swift peer-review system

Efficient typesetting and proofreading procedure

Display of the result of downloads and visits, as well as the number of cited articles Maximum dissemination of your research work

Submit your manuscript at: http://papersubmission.scirp.org/

Or contact eng@scirp.org 